\title{
DZIECKO, KOBIETA I UBOGI - GENEALOGIA (NEO)LIBERALNEGO WYKLUCZENIA
}

\begin{abstract}
Lewartowska-Zychowicz Małgorzata, Dziecko, kobieta i ubogi - genealogia (neo)liberalnego wykluczenia [Children, Women and the Poor - the Genealogy of Neo(liberal) Social Exclusion]. Studia Edukacyjne nr 33, 2014, Poznań 2014, pp. 147-164. Adam Mickiewicz University Press. ISBN 978-83232-2879-0. ISSN 1233-6688
\end{abstract}

The text covers the matter of social exclusion understood as limited access to social, political and economical life, and its justification. Its purpose is to face the provocative thesis that the intentional implementation of exclusion can be done on the basis of liberal theories. The source of such actions is the model of the rational individual, on which the liberals based their theory of personal autonomy. The exclusive potential of this concept caused the politics of exclusion applied to children, women and the poor. In children, limiting their personal autonomy was justified by the liberals due to its potential rationality and therefore a temporary inability to make independent decisions and take responsibility for itself. Exclusion practices towards women in early liberal societies are justified by separating the private sphere from the public sphere and liberating the former from any interference. This liberal idea influenced the process of perpetuating the pre-political home authority of men and blocked women's emancipation for many years. The exclusion of the poor from participating in liberal freedom is caused by the connection between personal autonomy and private property. The liberal guilt in this case is the full awareness of the excluding features of poverty, with strong commitment to political actions, radically increasing the process of countries holding power over the world growing poor.

Key words: liberal discourse, neoliberal ideology, social exclusion

Pedagogiczne zainteresowanie socjologiczną w istocie problematyką wykluczenia motywuję przekonaniem, że jest ono niezwykle ważnym elementem kontekstu społeczno-kulturowego, który tworzy zasadnicze okoliczności ludzkiego rozwoju i generuje dominujące pedagogie. Stąd pedagodzy, jak sądzę, są zobowiązani do wciąż na nowo podejmowanego wysiłku 
rozpoznawania owych okoliczności i przyjmowania ich za punkt wyjścia dla namysłu nad kierunkami przemian współczesnych praktyk edukacyjnych. Zobowiązanie to ciąży na nich tym bardziej, im głębiej towarzyszące im założenia dyskursywne są skrywane i kamuflowane, a z sytuacją taką - jak będę się starała dowodzić - mamy właśnie do czynienia.

Na użytek tego tekstu wykluczenie będę traktować jako praktykę wznoszenia różnorakich barier i przeszkód o charakterze strukturalnym, ale dyskursywnie skonstruowanych, które utrudniają lub uniemożliwiają ludziom pełne uczestniczenie w życiu społecznym, kulturowym, politycznym i ekonomicznym. Z racji przyjętej tu perspektywy pedagogicznej, owe polityczne praktyki strukturowania przestrzeni społecznej będę traktować jako zabiegi znaczące $\mathrm{z}$ punktu widzenia konstruowania się ludzkiej tożsamości w podwójnym sensie. W pierwszym - legitymizowanym przez dyskursywne zabiegi definiowania podmiotowości - wyznaczającym możliwe do pomyślenia sposoby opisywania tożsamości jednostkowej; i drugim - uzasadnianym przez interioryzację dyskursywnie skonstruowanych wersji podmiotowości - określającym możliwe do pomyślenia sposoby bycia w świecie.

Celem prezentowanego tekstu jest poddanie pod rozwage nieco prowokacyjnej tezy, że intencjonalnie realizowane praktyki wykluczenia mogą być inicjowane z pozycji liberalnych. Jej przewrotność polega tu na sproblematyzowaniu dość powszechnego na gruncie pedagogiki - i nie tylko - przeświadczenia, że liberalizm (przynajmniej w swojej klasycznej wersji) jest orientacją zdecydowanie inkluzywną, która bezwzględnie sprzyja wolności każdej pojedynczej jednostki.

Źródłem praktyk, o których mowa, jest klasyczno-liberalny model jednostki, który - jak sądzę - został skonstruowany w taki sposób, że zaczął służyć jako model legitymizujący inicjowanie polityki wykluczenia całych grup społecznych. O ile jednak w klasycznej fazie swojego rozwoju liberalizm cechował optymizm i zdecydowanie szlachetne intencje, owocujące wytworzeniem intelektualnego klimatu sprzyjającego finalnie - choć nie bez przeszkód - poszerzaniu autonomii jednostkowej, o tyle w zwyrodniałym neoliberalnym - wcieleniu okazał się on dyskursem skrajnie niebezpiecznym dla ideałów demokracji i egalitaryzmu, które po 1989 roku zaczęły się zakorzeniać w naszym współczesnym myśleniu o edukacji.

Osią owego liberalnego modelu jednostki uczyniono indywidualizm, traktowany jako pewien typ postawy, polegającej na skoncentrowaniu na własnej tożsamości, własnych wartościach i celach, związanych z samorealizacją. Rozumiany w sensie metodologicznym - umieszcza jednostkę w centrum wszelkich teorii społecznych i politycznych; w znaczeniu etycznym 
przyznaje pierwszeństwo indywidualnym prawom, potrzebom i interesom ${ }^{1}$. W każdym z tych wcieleń zdaje się służyć wyodrębnianiu się jednostki z różnorakich grup społecznych, za pośrednictwem których w społeczeństwie feudalnym była ona definiowana. Problem polega jednak na tym, że mówiąc o jednostce, liberałowie nie mieli w istocie na myśli konkretnej jednostki, tylko jednostkę abstrakcyjną o określonej jakości. Taką, która jest racjonalna i dopiero w związku z tym autonomiczna. Wolność jednostkowa realizuje się w tym ujęciu w sposób niejako zapośredniczony przez sprawny umysł, zdolny do dokonywania słusznych etycznie wyborów i podejmowania racjonalnych decyzji opartych na analizie relacji cel - środek. Na tej podstawie liberałowie przyznawali owej racjonalnej jednostce pełnię praw podmiotowych, na których straży postawili instytucję własności prywatnej i prawo. Przestrzenią życia racjonalnej jednostki miały się stać dwie równoległe sfery: prywatna i publiczna, z których pierwsza była miejscem szczelnie chronionym przed jakąkolwiek ingerencją zewnętrzną, druga natomiast była regulowana prawami, zabezpieczającymi równość i wolność aktywizmu wszystkich obywateli.

Liberalna koncepcja jednostki ma charakter uniwersalny, co oznacza tyle, że opisujące ją parametry mają dotyczyć wszystkich jednostek, bez względu na ich osadzenie społeczne, kulturowe, polityczne, czy jakiekolwiek inne. Jednostka to zatem człowiek w ogóle, odbijający się w każdym człowieku konkretnym. Z tego względu - jak deklarowali liberałowie - każdemu konkretnemu człowiekowi należy przyznać pełnię praw podmiotowych. A jednak tak się nie stało - w obrębie doktryny klasyczno-liberalnej od samego początku jej rozwoju formułowane były bowiem argumenty na rzecz ograniczenia dostępu do wolności podmiotowej pewnych konkretnych jednostek. Podobnie rzecz się miała w praktykach społeczeństw liberalnych.

Pierwszą ofiarą liberalnej polityki wykluczenia stało się dziecko.

\section{Dziecko - pierwszy akt genealogii liberalnego wykluczenia}

Autonomia jednostkowa została w liberalnej doktrynie umocowana w ludzkiej racjonalności. W tradycji francuskiej racjonalność warunkowała zdolność do dokonywania niezależnych wyborów, natomiast w tradycji brytyjskiej pozwalała na adekwatne szacowanie relacji cel - środek i dzięki

${ }^{1}$ A. Heywood, Ideologie polityczne. Wprowadzenie, przekł. M. Habura, N. Orłowska, D. Stasiak, Warszawa 2007, s. 43-44. 
temu czyniła ludzkie działania skutecznymi. Te dwa elementy były zaś traktowane jako kluczowe z punktu widzenia dostępu do wolności, będącej warunkiem samodzielnego konstruowania pożądanej jakości własnego życia.

Codzienne doświadczenie podpowiadało jednak liberałom, że dziecko nie jest zdolne do dokonywania aktów świadomego, racjonalnego wyboru i w oczywisty sposób nie jest zdolne do samodzielnego podtrzymania swojego życia, w związku z czym musi się zdać na swych opiekunów. Jako pierwszą i podstawową słabość wskazywali jego popędliwą naturę, która nie jest równoważona pracą jeszcze nierozwiniętego rozumu i dlatego dominuje $\mathrm{w}$ jego działaniach. Związana $\mathrm{z}$ nią potencjalna $\mathrm{i}$ anomijna natura dziecka polega $w$ tym kontekście na tym, że jeszcze nie ma ono władzy nad swymi skłonnościami i nie umie oprzeć się chwilowym pragnieniom. Przy czym, liberałowie nie ganią samego faktu posiadania pragnień, tylko dziecięcą niezdolność do poddawania ich kontroli rozumu².

W tym kontekście liberalna doktryna za jednostkę racjonalną musiała (w sensie logicznym rzecz jasna) uznać zdrową na umyśle dorosłą osobę, natomiast dziecko za racjonalne tylko potencjalnie. W konsekwencji, nie mogła mu przyznać pełni praw podmiotowych. Odmówienie autonomii dziecku odnosi się więc $\mathrm{w}$ tym ujęciu do czasowego zniewolenia go przez jego własne słabości wewnętrzne i w związku z tym czasowego niedostatku racjonalności ${ }^{3}$.

W doktrynie liberalnej te dwie postaci - dziecko i dorosłego - oddzielił więc dystans, którego skracanie wiązało się z wysiłkiem nabywania racjonalności w toku społecznych doświadczeń i w efekcie zorganizowanej edukacji. Ów dystans legitymizował rodzicielską i nauczycielską władzę nad dzieckiem, wynikającą z faktu, że dziecko nie rozumuje, toteż nie jest w stanie kierować się wolą, by zgodnie z nią postępować. Potrzebny jest mu w związku z tym ktoś, kto za nie będzie rozumować i za nie też będzie wyrażać wolę ${ }^{4}$.

Tym niemniej, w konsekwencji jego nakreślenia znaczenie słowa „dziecko" nie pokrywa się ze znaczeniem słowa „człowiek", a prawa człowieka nie są tym samym, co prawa dziecka ${ }^{5}$. Szansą nabycia pełni praw podmiotowych jest dla dziecka swoista emigracja z przestrzeni prywatnej (rodziny) do publicznej (szkoły) w celu osiągnięcia pełni człowieczeństwa ${ }^{6}$. Stanowi

2 J. Locke, Dwa traktaty o rzadzie, przekł. Z. Rau, Warszawa 1992, s. 29.

${ }^{3}$ M. Lewartowska-Zychowicz, Homo liberalis jako projekt edukacyjny. Od emancypacji do funkcjonalności, Kraków 2010, s. 133.

4 Tamże, s. 205-207.

5 Sz. Wróbel, R. Nawrocki, Szkoła jako fikcja i inne szkice z filozofii edukacji, Kalisz-Poznań 2010, s. 162.

${ }^{6}$ Tamże, s. 161. 
ona kluczowy mechanizm inkluzyjny. Edukacja jest w tym kontekście miejscem przygotowywania się do autonomicznego życia w warunkach czasowego zawieszenia praw podmiotowych, pomimo że jest częścią przestrzeni publicznej, gdzie te prawa obowiązują. Jej sens sprowadza się do inicjowania i kontrolowania przebiegu dojrzewania intelektualnego, pozostającego w związku z wolnością jednostkową, rozumianą substancjalnie jako prywatna sfera dowolnego (w granicach prawa) postępowania ${ }^{7}$.

Dla Locke'a polegała ona na stłumieniu za pomocą rozumu popędliwej natury dziecka. Według A. Smitha, rozum miał jedynie kontrolować popędy, u J.St. Milla - pełnić wobec nich rolę kierowniczą. $W$ tradycji brytyjskiej podkreślano również tę funkcję rozumu, która miała związek z autonomią ludzkiego myślenia, niezależnością sądów i wypowiedzi, które były podstawą samodzielnego, skutecznego działania ${ }^{8}$.

Celem finalnym edukacji miało być $\mathrm{w}$ tym ujęciu wyprowadzenie dziecka ze stanu anomii i doprowadzenie go do autonomii w myśleniu i działaniu, możliwej w wyniku nabywania przez nie umiejętności konstruowania własnych poglądów oraz ich argumentowania, a także pozyskiwania narzędzi niezależnego formułowania celów i racjonalnego szacowania dostępnych środków ich realizacji. Problem w tym, że owa potencjalna zaledwie autonomia uczyniła z dziecka e-ducatio, istotę która definiowana jest nie przez swoje właściwości, ale przez swoje braki w odniesieniu nie tyle do dorosłego, ile do dyskursywnie skonstruowanego wzorca podmiotowości jednostki dojrzałej. Dziecięca tożsamość zmierzająca dopiero do autonomii, musiała być poddana $\mathrm{w}$ tym kontekście zabiegom dyscyplinującym $\mathrm{w}$ przeznaczonych do tego celu profesjonalnych placówkach, nazywanych szkołami.

Szymon Wróbel opisując szkołę używa kontrowersyjnej metafory obozu, takiego jak Guantanamo, w którym legalnie i prawomocnie odbiera się pewnej grupie ludzi ich podstawowe prawa: wolności osobistej, wolności słowa i działania9. Trudno jednak zaprzeczyć, że nawet najbardziej liberalna szkoła tak właśnie czyni w nadziei, że przez zniewolenie doprowadzi dzieci do wolności. W tym sensie liberalna edukacja nie różni się zasadniczo od konserwatywnej, rzecz jasna poza punktem docelowym, którym dla dyskursu konserwatywnego jest odtwarzanie zastanego porządku społecznego, dla liberałów natomiast - autonomia jednostkowa. Nawiasem mówiąc, zbadanie zbieżności owej drogi prowadzącej do różnych celów mogłoby wiele powie-

${ }_{7}$ S. Hessen, Pisma pomniejsze, [w:] Dzieła wybrane, wybór i oprac. W. Okoń, t. V, Warszawa 1997, s. 13.

${ }^{8}$ M. Lewartowska-Zychowicz, Homo liberalis jako projekt edukacyjny, s. 135.

${ }_{9}$ Tamże, s. 164. 
dzieć o przyczynach bezkonfliktowego wiązania podstawowych tez konserwatywnych i liberalnych we współczesnym dyskursie neoliberalnym.

Legitymizację dla liberalnych działań dyscyplinujących tożsamość stanowi pęknięcie, zawarte $\mathrm{w}$ liberalnym myśleniu o warunkowej powszechności praw podmiotowych, które uwidacznia się jednak wyraźnie dopiero wówczas, kiedy odniesiemy je do pedagogicznej orientacji pajdocentrycznej, na gruncie której dziecko nie jest tak, jak dla liberałów potencjalnym człowiekiem, ale człowiekiem w pełni. Przyznaje mu się zatem te same prawa, którymi cieszą się dorośli, by mogło funkcjonować jako samookreślający się podmiot własnego działania, który nie jest niczyją własnością ${ }^{10}$.

Liberałowie, jak widać zablokowani kategorią racjonalności, nie zdołali odnieść idei praw i wolności podmiotowych do dziecka, chociaż skonstruowali dyskurs, który przyczynił się do wytworzenia klimatu intelektualnego, towarzyszącego rodzącej się kulturze liberalnej początku XX wieku. Jego kwintesencją stały się typowo liberalne postulaty, takie jak prawo do wolności i odpowiedzialności - tyle że po raz pierwszy odnoszone do dziecka. Głoszone jednak już nie przez liberałów. Paradoksalnie można zatem powiedzieć, że do narodzin dyskursu praw dziecka nie przyczynił się liberalizm, który dysponował nieomal monopolem na tę kategorię, ale ogólny klimat intelektualny, który powstał w efekcie liberalnego argumentowania na rzecz poszerzania praw jednostkowych dorosłych. Sama myśl liberalna pozostawała natomiast $\mathrm{w}$ sztywnej ramie konwencji Arystotelesowskiego sposobu definiowania dziecka przez brak i niedostatek, legitymizujący utrzymywanie nad nim władzy dorosłych - rodziców i nauczycieli. Z perspektywy praw dziecka i jego dostępu do autonomii osobistej miała zatem charakter zdecydowanie ekskluzywny.

\section{Zapomniana kobieta - akt drugi genealogii liberalnego wykluczenia}

Inaczej niż w przypadku dzieci, ograniczenie dostępu do liberalnie rozumianej wolności kobietom miało charakter niejawny i nie znajduje wprost odbicia $\mathrm{w}$ liberalnej doktrynie, lecz raczej w konserwowaniu tradycyjnych praktyk ekskluzyjnych przez nowy liberalny porządek społeczny, w braku dostatecznego zaangażowania liberałów w ich przełamywanie i tworzeniu

10 Th. Gordon, Wychowanie bez porażek, przekł. D. Szafrańska-Poniewierska, Warszawa 2004. 
nowych mechanizmów wykluczenia. Ta opieszałość, lub jak chcą niektóre badaczki feministyczne - przeoczenie, ma swoje źródło w liberalnym modelu jednostki - racjonalistycznym i uniwersalistycznym.

Właściwością autonomicznej jednostki ma być bowiem, zdaniem liberałów, racjonalny umysł. Tymczasem, na gruncie tradycji mamy do czynienia z rozpowszechnioną akceptacją idei dymorfizmu płciowego, zgodnie z którym kobieta i mężczyzna różnią się między sobą - mężczyzna jest raczej racjonalny, kobieta zaś raczej emocjonalna. Liberalne myślenie o przedracjonalnej i anomijnej naturze dziecka przypominało utrwalony tradycją stereotyp miotanej popędami kobiety, w rezultacie czego trudno było z pozycji liberalnych podjąć kwestię jej emancypacji. Kobieta, podobnie jak dziecko, stała się jeszcze nie podmiotem i - co ważniejsze - dorosłym jeszcze nie podmiotem. Takim zatem, któremu już nie towarzyszy oczekiwanie na autonomię w przyszłości. Liberalnie ujmowana kategoria podmiotowości konserwowała zatem stereotypowe myślenie o kobiecie i wyłączyła ją z dyskursu wolnościowego.

$\mathrm{Na}$ jego utrwalanie szczególny wpływ miał również uniwersalizm liberalnego podejścia do człowieka. Liberałowie nie przepracowali bowiem dyskursywnie faktu, że na rodzaj ludzki składają się mężczyźni i kobiety, którym tradycyjne społeczeństwo wyznaczyło inny los i w toku reprodukcji kulturowej konsekwentnie eliminowało pewne ich cechy, a wzmacniało inne. Pisali natomiast o człowieku w ogóle. Zastąpienie zróżnicowanych bytów ludzkich pojęciem niezróżnicowanego człowieka uniwersalnego sprzyjało tymczasem dyskursywnej neutralizacji istniejącej faktycznie różnicy położenia ze względu na płeć. Teza o tym, że człowiek nie jest ani mężczyzną, ani kobietą stabilizowała więc tradycyjne nierówności w sferze życia rodzinnego, społecznego, politycznego i ekonomicznego ${ }^{11}$. Podobnie abstrakcyjna i formalna równość wszystkich ludzi - jak się okazało - nie wpłynęła na wyrównywanie faktycznych różnic $\mathrm{w}$ ich położeniu, których geneza $\mathrm{w}$ biografiach jednostkowych sięga $\mathrm{z}$ pewnością procesu urodzajowionej tradycyjnej socjalizacji i edukacji. Przeciwnie - wydaje się, że uczyniła je nawet tym bardziej niewidocznymi.

Dlatego, w liberalnym już społeczeństwie mężczyźni nadal byli kształceni w zakresie odwagi, umiarkowania, sprawiedliwości i hartu ducha, czyli cnót obywatelskich; kobiety natomiast - $\mathrm{w}$ zakresie miękkich kompetencji i takich właściwości, jak cierpliwość, uległość i pokora, które miały z nich uczynić dobre żony i matki ${ }^{12}$.

${ }^{11}$ S. Agacinski, Polityka ptci, przekł. M. Falski, Warszawa 2000, s. 86-88.

12 R. Putnam Tong, Myśl feministyczna. Wprowadzenie, przekł. J. Mikos, B. Umińska, Warszawa 2002, s. 23. 
Edukacja w społeczeństwie liberalnym nadal reprodukowała zatem zasadniczą nierówność kobiet i mężczyzn, bo w imię hipotetycznej natury kobiet utrudniała im dostęp do rozwijania racjonalności, a tym samym autonomii w liberalnym znaczeniu tego słowa. Na tę jej właściwość zwrócił uwagę dopiero J.St. Mill, który był orędownikiem zmiany systemu kształcenia kobiet, jednak i on uważał, że kobieta wykształcona, która wychodzi za mąż - sama wybiera gospodarstwo domowe i wychowanie dzieci za główny cel swojej aktywności życiowej, a poza tym nikt nie zrobi tego lepiej od niej $^{13}$. Jak pisał, nikt nie powinien zamężnym kobietom przeszkadzać w realizowaniu aspiracji, byle tylko umiały zaradzić mogącemu w związku z tym powstawać zaniedbaniu obowiązków gospodyni domowej ${ }^{14}$. Za główną korzyść z ich wykształcenia uważał zaś intelektualne stymulowanie swojego męża ${ }^{15}$, a nie perspektywę wzięcia satysfakcjonującego i społecznie owocnego udziału w życiu publicznym. W dziełach klasyków liberalnych nie sposób, jak się okazuje, odnaleźć zasadniczej zmiany w sposobie identyfikowania kobiet, istotnej modyfikacji w myśleniu o możliwych do zajęcia przez nią pozycjach społecznych. Wydaje się, że - paradoksalnie - doktryna liberalna pod względem myślenia o kobietach pozostawała bardzo konserwatywna i raczej utrwalała nierówności, niż je odsłaniała i przełamywała. Dodatkowym czynnikiem ekskluzyjnym było to, że w odniesieniu do utrwalonych tradycją, potocznych przekonań o zasadniczej niższości kobiet, które miały charakter jawny (i dzięki temu prawem kontrastu lepiej widoczny $\mathrm{w}$ rodzącej się kulturze liberalnej), dyskurs liberalny zainicjował praktykę dyskursywnego neutralizowania i maskowania praktyk wykluczających kobiety z pełnego udziału w życiu publicznym, co nie pozostało bez wpływu na ich utrwalanie się $\mathrm{w}$ sferze życia społecznego i w obszarze interioryzacji typowych wzorów ról.

Nierówności ze względu na płeć kamuflowało i konserwowało szczególnie, uzasadnione dyskursem wolnościowym, rozdzielenie sfery prywatnej i publicznej oraz wyłączenie tej pierwszej spod jakiejkolwiek ingerencji zewnętrznej. W zamyśle liberałów miało ono chronić społeczności przed wybuchami namiętności i konfliktami na tle światopoglądowym, spowodowanymi różnicami, przez spychanie ich do sfery prywatnej. Faktycznie jednak sprzyjało umacnianiu przedpolitycznej siły, za pomocą której głowa rodziny rządziła domownikami. Jej władza była już na gruncie tradycji od-

13 J.S. Mill, Poddaństwo kobiet, [w:] O rządzie reprezentatywnym, przekł. J. Hołówka, Kraków 1995, s. 332.

14 Tamże.

15 Tamże, s. 366. 
czuwana jako naturalna i konieczna ${ }^{16}$, liberałowie natomiast dostarczyli jej podtrzymaniu kolejnego argumentu, jakim była autonomia osobista w sprawach prywatnych, stąd tym trudniejsze stało się poddanie jej poważnej debacie publicznej ${ }^{17}$. Liberalna doktryna przyczyniła się do powstania nowej formy legitymizacji tej władzy przez wyłączenie sfery prywatnej z dyskursu wolnościowego. Władza prywatna ma natomiast kluczowe znaczenie dla położenia kobiet (jak i dzieci) i szans ich dostępu do edukacji oraz - w perspektywie - uzyskania wpływu na życie publiczne.

Szczególnym aspektem męskiej władzy w sferze prywatnej była zależność ekonomiczna kobiet, ponieważ - zgodnie z myślą (i praktyką) liberalną - własność prywatna jest konstytutywnym warunkiem ludzkiej autonomii. Skoro zaś kobiety zostały faktycznie pozbawione możliwości pozyskiwania osobistej własności, a w przypadku jej dziedziczenia nie miały prawa zarządzania nią - ich emancypacja została zablokowana na poziomie strukturalnym. F. Engels upatruje genezy owej nierówności w zakresie dostępu do własności prywatnej, w zainicjowanym w społecznościach pierwotnych przemieszczaniu się miejsca produkcji z obszaru gospodarstwa domowego w kierunku jego zewnętrza, które dokonało się wraz z udomowieniem zwierząt i rozpoczęciem ich hodowli. Nowe praktyki gospodarowania, w których uczestniczyli głównie mężczyźni, doprowadziły bowiem do wytworzenia przez nich nadwyżki zasobów, w związku z czym wyłonił się problem ich dziedziczenia. $W$ miarę rozwoju społeczeństw, prawo macierzyste zostało zatem zastąpione prawem patrylinearnym, które gwarantowało jednokierunkowy transfer zasobów od mężczyzny do jego syna. Ich pozyskiwanie i posiadanie nabierało $\mathrm{z}$ kolei znaczenia $\mathrm{w}$ utrwalaniu nowej struktury sprawowania władzy. Engels wnioskuje stąd, że mechanizmy władzy mężczyzn nad kobietami umocowane są przede wszystkim w instytucji własności prywatnej ${ }^{18}$. Doktryna liberalna "przeoczyła" natomiast fakt, że społeczności tradycyjne wytworzyły mechanizmy blokowania kobietom dostępu do własności prywatnej, a liberałowie pozostali również niewrażliwi na to, że te dyskryminujące praktyki wobec kobiet były wzmacniane przez praktyki wczesnego kapitalizmu, który wyprowadził ostatecznie pracę ze sfery prywatnej do publicznej, wytworzył podział na pracę produkcyjną, będącą domeną mężczyzn, i pracę nieprodukcyjną, będącą domeną ko-

\footnotetext{
${ }^{16}$ H. Arendt, Kondycja ludzka, przekł. A. Łagodzka, Warszawa 2000, s. 37.

17 S. Benhabib, Trzy modele przestrzeni publicznej, przekł. A. Ostolski, „Krytyka Polityczna” z 2003, 3, s. 85.

${ }^{18}$ F. Engels, Pochodzenie rodziny, własności prywatnej i państwa, [w:] Karol Marks, Fryderyk Engels, Dzieła, t. 21, Warszawa 1969, s. 61-74.
} 
biet $^{19}$ - i na koniec - przyczynił się do wzbogacenia się mieszczaństwa, a raczej mężczyzn z tej klasy, którzy zdołali swoje żony i córki osadzić w domu i uczynić ozdobą ich dostatniego stylu życia.

Początkowo rozwój społeczeństw kapitalistycznych zmierzał w kierunku wprowadzenia kobiet na rynek pracy produkcyjnej, jednak jak sądzą przedstawicielki feminizmu marksistowskiego i socjalistycznego, wkrótce liberalne (a zwłaszcza neoliberalne) reformy doprowadziły do tego, że dla kobiet pozostają obecnie do dyspozycji głównie zajęcia stanowiące ekwiwalent tradycyjnych prac domowych (opieka nad dziećmi, starcami lub chorymi, nauczanie, sprzątanie). Pozyskiwane przez nie wynagrodzenie częściej stanowi uzupełnienie budżetu domowego, niż główne źródło dochodu rodziny. Iris Young uważa, że marginalizacja kobiet i, co za tym idzie, ich rola drugorzędnej siły roboczej stanowi zasadniczą i podstawową cechę kapitali$z^{2 m u}{ }^{20}$. Jeśli tak, to autonomia - zgodnie z doktryną liberalną - mocowana we własności prywatnej pozostanie dla kobiet trudno dostępna, a one same raczej niewidzialne dla dyskursu liberalnego (o ile, rzecz jasna, same o siebie się nie zatroszczą).

Doktryna liberalna, która jak widać przeoczyła zniewolenie kobiet w społeczeństwie tradycyjnym i utrwaliła ich podporządkowaną pozycję w społeczeństwie liberalnym, stała się jednak inspiracją dla ruchu feministycznego, który powołując się na liberalną teorię upomniał się o polityczne prawa kobiet. Liberalne uniwersalistyczne myślenie zaciążyło jednak na wczesnym ruchu feministycznym prowadząc go do programu emancypacji, który sprowadzał się do hasła: „aby kobieta była równa mężczyźnie, musi się stać taka sama, jak on". Emancypacja kobiet miała zatem polegać na, wzorowanych na dojrzewaniu dziecka, próbach pozbywania się swojego braku i dołączaniu dzięki temu do uniwersalizmu człowieczeństwa. Dopiero kolejna fala feminizmu przyniosła uznanie równowartościowości zróżnicowania, wyrażone w haśle „aby kobieta była równa mężczyźnie, społeczeństwo musi nauczyć się cenić tak samo to, co kobiece, jak ceni to co męskie"21. Badaczki feministyczne, które dokonały tego odkrycia, odsłoniły równocześnie ograniczenia liberalnego myślenia o emancypacji osadzonego $\mathrm{w}$ uniwersalistycznej koncepcji racjonalnej jednostki, które prowadzi wprost do „wiecznego dziecięctwa kobiety".

${ }^{19}$ S. de Beauvoir, Druga płeć, Kraków 1972, s. 48.

${ }^{20}$ I. Young, Beyond the unhappy marriage: a critique of the dual systems theory, [w:] Women and revolution: a discussion of the unhappy marriage of marxism and feminism, red. L. Sargent, Boston 1981, s. 62.

${ }^{21}$ R. Putnam Tong, Myśl feministyczna, s. 43. 


\section{Ubogi \\ - neoliberalny akord liberalnej genealogii wykluczenia}

Praktyki wykluczania nabrały tempa i rozmachu wraz z intensyfikującymi się na świecie od lat osiemdziesiątych, a w Polsce od 1989 roku, przemianami rynkowymi, uzasadnianymi zdogmatyzowaną ideologią neoliberalną. Ich ofiarą stali się tym razem ubodzy ( $w$ tym zwłaszcza ubogie kobiety i dzieci). O ile jednak liberalne blokowanie dostępu do wolności podmiotowej dzieci miało charakter czasowy i przekonującą, bo umocowaną $\mathrm{w}$ doświadczeniu potocznym argumentację, a utrwalanie zniewolenia kobiet wydawało się niezamierzone i przypadkowe, o tyle wykluczenie ubogich jest jawnym sprzeniewierzeniem się emancypacyjnej istocie doktryny liberalnej. Neoliberalna „wina” polega tu na pełnej świadomości wykluczającego charakteru ubóstwa i równoczesnym radykalnym zwiększeniu liczby ubogich.

Liberalna teoria wolności od początku była bowiem osadzana w instytucji własności prywatnej. Najmocniej wyakcentował ten związek J. Locke w regule: nie ma wolności bez prawa do własności prywatnej. Dlatego, za pierwszą i podstawową uznał wolność gospodarczą, rozumianą jako swoboda pozyskiwania i dysponowania własnym dochodem i użytkowania własnych zasobów ${ }^{22}$. Na niej dopiero miała powstawać autonomia osobista, która jest źródłem aktywizmu, rozwoju i emancypacji jednostki ${ }^{23}$. W ten oto sposób liberałowie zdefiniowali również ścisły związek między własnością a aktywnością polityczną, polegający na pozyskiwaniu wolności w sferze politycznej dzięki niezależności w sferze ekonomicznej. Założenie o pierwszeństwie sfery ekonomicznej wobec politycznej ma swoje wyjaśnienie w określonej przez Locke'a zasadzie, że człowiek żyje przede wszystkim w społeczeństwie będącym zespołem relacji wymiany ekonomicznej, w którą zaangażowani są pracownicy i właściciele, a dopiero później w instytucjach politycznych, które stoją na straży zachowania uczciwych reguł gromadzenia i obrotu własnością. W interpretacji Locke'a kolejność ta wynika z mechanizmu wychodzenia człowieka ze stanu natury, polegającego na przydawaniu naturze swojej pracy i nabywaniu w związku z nią (naturalnego) prawa własności do przedmiotu i owoców tej pracy. Na oznaczenie owego przyrostu obfitości, który powstaje w rezultacie wykonanej pracy, wprowadził on pojęcie wartości, wyrażane w życiu społecznym przez konwencjonalny wynalazek pieniądza. Pieniądz oddziela jednak zrodzoną

\footnotetext{
${ }^{22}$ M. i R. Friedman, Wolny wybór, przekł. J. Kwaśniewski, Sosnowiec 2006, s. 61-62.

${ }^{23}$ L. von Mises, Liberalizm w tradycji klasycznej, przekł. S. Czarnik, Kraków 2001, s. 97.
} 
W stanie natury więź między prawem pracownika a prawem właściciela. Dlatego, we współczesnych społeczeństwach kapitalistycznych idzie już nie tyle o wytwarzanie własności, ile bardziej o wytwarzanie wartości. Prawo własności zostaje oczywiście zachowane, jednak prawo pracownika zaczyna dotyczyć nie własności, tylko wytworu pracy. Tym samym, indywidualistyczne i emancypacyjne uzasadnienie prawa własności, charakterystyczne dla wczesnej doktryny liberalnej, zaczęło się przekształcać w teorię ekonomicznej użyteczności. Prawo własności przestało bowiem pełnić rolę gwarantującego wolność podstawowego prawa naturalnego człowieka i zaczęło służyć jako środek zachowania wartości powstałej z produktywności ludzkiej pracy ${ }^{24}$. W konsekwencji tego przesunięcia, liberałowie mogli się poczuć zwolnieni z troski o zachowanie (faktycznych, a nie tylko formalnych) swobodnych i równych warunków dostępu do pozyskiwania, gromadzenia i obrotu własnością. I rzeczywiście, w dyskursie neoliberalnym dostrzegalne są wyraźnie przemieszczenia w myśleniu o relacji własność - wolność. Nawiązując do szkockiej szkoły ekonomii, neoliberałowie dowodzą bowiem, że idzie nie tyle o samą własność, ile o swobodę obrotu zasobami, bez której wolność osobista i polityczna nie mogą istnieć25. Dlatego, pojawienie się wolności wiążą wyłącznie $\mathrm{z}$ rozwojem kapitalizmu, a zwłaszcza wolnego handlu, dzięki któremu - jakoby - przełamane zostały bariery społeczne i zniesione poddaństwo ${ }^{26}$. Zmniejszenie stopnia dyskryminacji i poszerzenie pól wolności miało towarzyszyć rozwojowi kapitalizmu dlatego, że rynek dostarcza bodźców do oddzielenia zdolności produkcyjnej od innych cech człowieka27. Wolność każdego - pracownika, pracodawcy, producenta i konsumenta jest chroniona przez fakt istnienia innych pracowników, pracodawców, producentów i konsumentów, spośród których można wybierać28. Kwintesencją neoliberalnej wolności stała się więc wolność wyboru29, ale już bez określenia warunków brzegowych owego wyboru, do jakich nawiązywał A. Smith (przede wszystkim braku monopoli i doskonałego dostępu do informacji).

Dlatego, wraz z nowym kierunkiem rozwoju wolnego rynku, według reguł doktryny neoliberalnej, szybko okazało się, że neoliberalne praktyki

\footnotetext{
24 P. Manent, Intelektualna historia liberalizmu, przekł. M. Miszalski, Kraków 1994, s. 70-74.

${ }^{25}$ F.A. von Hayek, Droga do zniewolenia, przekł. K. Gurba, L. Klyszcz, J. Margański, D. Rodziewicz, Kraków 2003, s. 25.

26 A. Rand, Rasizm, [w:] Powrót człowieka pierwotnego. Rewolucja antyprzemystowa, przekł. Z.M. Czarnecki, Poznań 2003, s. 237-238.

${ }^{27}$ M. Friedman (przy współpracy Rose Friedman), Kapitalizm i wolność, przekł. M. Lasota, A. Kondratowicz, Warszawa 1993, s. 105-106.

${ }^{28}$ M. i R. Friedman, Wolny wybór, s. 236.

${ }^{29}$ L. von Mises, Mentalność antykapitalistyczna, przekł. J.M. Małek, Kraków 1999, s. 48.
} 
przyczyniają się zarówno do wytwarzania trwałego ubóstwa na bazie bezrobocia bez dróg powrotu do zatrudnienia, jak i ubóstwa wynikającego ze spadku wartości pracy. Formalna swoboda aktywności gospodarczej nie zmieniła natomiast znanej od starożytności reguły, że bieda zmusza wolnego człowieka do tego, by postępował jak niewolnik ${ }^{30}$. Wytwarzanie ubóstwa jest zatem wprost przyczynianiem się do zniewalania ludzi, gdyż ogranicza nie tylko pulę dostępnych im wyborów, ale również ich szeroko rozumiane szanse życiowe.

Udział polityki neoliberalnej w globalnym ubożeniu wynika z logiki nieograniczonego wzrostu i zysku, z której wyprowadza się podstawowe kierunki politycznego działania:

- prywatyzacje

- deregulację

- cięcie wydatków publicznych.

Neoliberalne credo (prywatyzacja, deregulacja i cięcie wydatków publicznych) narzucane światu za pomocą akcji kredytowej międzynarodowych instytucji finansowych (MFW, Banku Światowego) i lokalnych rządów, generuje gwałtowne zmiany w gospodarkach lokalnych, które mają bezpośrednie przełożenie na masowe wytwarzanie ubóstwa. Nie są one, rzecz jasna, całkowicie nowym zjawiskiem, lecz raczej wyrazem zwyrodnienia praktyk zrodzonych dzięki wczesnej myśli liberalnej. Daniel Bensaid szuka ich źródeł w orientacji klasycznej myśli liberalnej na indywidualizowanie prawa własności, czego odległym owocem jest obecna radykalna prywatyzacja. Wskazuje on na wprowadzenie przez liberałów nowego kodu definiowania własności i narzuceniu nowego, opartego na indywidualizmie prawa, zrywającego z zasadami zwyczajowymi. Dotyczące biedoty prawa zwyczajowe miały swoje źródło w chwiejnym prawie pewnego typu własności, nie będącej własnością zdecydowanie prywatną, ani zdecydowanie społeczną, mającej jednak kluczowe znaczenie egzystencjalne dla ubogich, bo zapewniającej jej ekonomiczne przetrwanie. W nowym prawie opartym na nowoczesnym rozumie własność nabrała charakteru cywilnego i zniosła niezbywalne prawo ubogich do dobra wspólnego oferowanego przez przyrodę. Nowi feudałowie rodzącej się epoki kapitalizmu ograniczyli zatem te prawa ludowe, które umożliwiały biedocie korzystanie $\mathrm{z}$ gruntów (prawo przechodu, prawo wypasu, prawo zbierania pokłosia, prawo zbierania martwego drewna $)^{31}$.

${ }^{30}$ H. Arendt, Kondycja ludzka, s. 71.

${ }^{31}$ D. Bensaid, Wywłaszczeni. Marks, własność i komunizm, przekł. Z.M. Kowalewski, Warszawa 2010, s. 25-26. 
Kiedy więc $\mathrm{w}$ dyskursie liberalnym podmiot indywidualny stał się miarą praktyk społecznych, definiowanie własności w odniesieniu do niego przybrało postać kategorii własności prywatnej. „W dobie klasycyzmu status własności ewoluował więc stopniowo ku absolutyzmowi własności. Ze stanu dobra przeszła ona w stan prawa podmiotowego" ${ }^{32}$. Absolutyzacja własności oznacza w tym kontekście przede wszystkim zniesienie względności własności feudalnej. Prawo podmiotowe nie zadowala się bowiem regulacją stosunków między jednostkami ludzkimi, jak czyniło to prawo feudalne „prowadzi ono wprost do podejmowania działań prawnych”33, sprowadzających się do wyzucia ubogich z dotychczasowych praw. Pierwszym aktem, legitymizowanego prawami podmiotowymi, ograniczania praw nieposiadających było, zapoczątkowane w Anglii w końcu XV wieku, grodzenie własności gminnej przez wielkich właścicieli ziemskich. Ostatnim stała się kapitalistyczna globalizacja, definiowana przez Davida Harveya jako kolejna w historii "akumulacja przez wywłaszczenie" 34 . Obecnie dotyczy ona jednak nie tylko gruntu, czy wody, ale obejmuje również znaczenia, odkrycia i generalnie - wytwory myśli, wcześniej traktowane jako wspólny dorobek ludzkości. Jednym z groteskowych tego przykładów jest spór prawniczy toczony przez firmę Apple $\mathrm{z}$ równie znaną marką Samsung o prawa patentowe do kształtu prostokąta pomalowanego na czarno ${ }^{35}$.

Zjawisko masowego ubożenia ma też swoje źródło w neoliberalnej polityce deregulacji rynków krajowych, która wypchnęła lokalnych producentów z krajów mniej rozwiniętych na światowe rynki towarowe, na których nie są oni w stanie wytrzymać konkurencji z produktami (często dotowanymi) bardziej rozwiniętych gospodarek. Paradoksalnie, nacisk międzynarodowych instytucji finansowych na deregulację pozostaje w sprzeczności z praktykami protekcjonistycznymi, które były przyjęte w tzw. Pierwszym Świecie wówczas, kiedy ten się rozwijał. Pouczający jest tu zwłaszcza przykład Wielkiej Brytanii, która jako znany w świecie promotor wolnego handlu, w 1820 roku miała cła na poziomie $45-55 \%$. Nie jest ona jednak odosobnionym przypadkiem. Podobnie czyniła czołówka najbogatszych obecnie krajów, które chroniły swój przemysł przed zagraniczną konkurencją, dopóki nie stał się na tyle silny, że sam sobie radził na światowych rynkach. Podobnie postępowały Francja, Austria, Norwegia, Finlandia, a przede wszystkim Stany Zjednoczone, gdzie cła importowe w latach 30. i 40. wynosiły do $50 \%$. Jak pisze niemiecki ekonomista Friedrich List,

\footnotetext{
32 Tamże, s. 31 .

33 Tamże.

34 D. Harvey, Neoliberalizm. Historia katastrofy, przekł. J.P. Listwan, Warszawa 2008, s. 213- 222.

35 S. Stodolak, Absurd patentowany, „Wprost” z 11 września 2011.
} 
w 1841 roku kraj, z którego przemysłowi nikt na świecie nie jest w stanie dorównać, nie może zrobić nic mądrzejszego niż ogłosić, że wcześniej zbłądził na drogę protekcjonizmu, a teraz powraca na właściwą drogę wolnego handlu i namawia wszystkich do zrobienia tego samego ${ }^{36}$.

Najbardziej dramatyczne skutki polityki deregulacji odnotowywane są tzw. krajach Trzeciego Świata. Deregulacja jest tam wynikiem wprowadzenia programów dostosowania strukturalnego, wymuszanego przez presję zadłużeniową. W ich konsekwencji dochodzi do gwałtownego ubożenia ludności z terenów rolniczych i potężnej migracji chłopów do miast, powodującej zjawisko tzw. nadurbanizacji bez wzrostu. Mike Davis uważa, że programy dostosowania strukturalnego, serwowane krajom rozwijającym się przez międzynarodowe instytucje finansowe, są wraz z czasowym koncentrowaniem taniej siły roboczej przez międzynarodowe koncerny wprost odpowiedzialne za powstawanie na masową skalę okołomiejskich i wielkomiejskich slumsów. Jest to zjawisko dobrze już opisane w literaturze przedmiotu. Istotny jest jednak mniej znany jego aspekt, na który zwraca uwagę Davis, a mianowicie - dzisiejsza polityka deregulacyjna sprzęga się z polityką wywłaszczeniową i na koniec przybiera znamiona działalności uwłaszczeniowej. Ten przedziwny splot brutalnej siły i iluzji widoczny jest w opisywanych przez Mike'a Davisa programach pomocowych MFW, adresowanych do mieszkańców slumsów. Clou stanowi projekt ich uwłaszczenia, który przybiera postać rozwarstwienia społecznego. Chodzi w nim nie tyle o nadanie ubogim prawa własności do gruntu, który zajmują, ile raczej o włączenie ich do bazy podatkowej. „Za korzyści płynące z możliwości wykorzystania domu jako zabezpieczenia prawnego płaci się tym, że jego właściciel staje się widoczny dla fiskusa" ${ }^{\prime 3}$. Dodatkowym bonusem dla beneficjentów polityki neoliberalnej jest wzrost cen ziemi i mediów oraz spekulacje nieruchomościami, które szybko pozbawiają ubogich świeżo nabytej własności i umożliwiają bogatszym odzyskanie terenów podmiejskich zajmowanych przez slumsy. Jest to więc szeroko zakrojona polityka wywłaszczenia przez uwłaszczenie, której skutkiem jest przemieszczanie się ubogich na jeszcze dalsze tereny, z których jeszcze trudniej dotrzeć do pracy w mieście. $\mathrm{W}$ rezultacie, miejscy ubodzy stają się nomadami, wciąż wyrzucanymi pod różnymi pozorami: raz jest to akcja oczyszczania miasta, raz walka o poprawę bezpieczeństwa, innym razem budowa dróg, stadionów, czy centrów handlowych ${ }^{38}$. Warto pamiętać, że analizy te nie dotyczą wyłącznie odległego Trzeciego Świata. Właściwe dla gospodarek przejściowych ubóstwo istnieje

\footnotetext{
${ }^{36}$ A. Piński, Polska biedna na zawsze, „Wprost” z 10 grudnia 2012.

${ }^{77}$ M. Davis, Planeta slumsów, przekł. K. Bielińska, Warszawa 2009, s. 139.

38 Tamże, s. 151.
} 
też w zurbanizowanej Europie Wschodniej. W Sofii na przykład eksplozja ubóstwa nastąpiła w latach 1995-1996 i dotknęła zwłaszcza mniejszość romską i turecką. W stolicy Bułgarii, w dzielnicy Fakulteto mieści się prawdopodobnie największy w Europie slums ${ }^{39}$.

Marginalizacja mieszkaniowa jest natomiast równoznaczna z marginalizacją $\mathrm{w}$ sferze zatrudnienia ${ }^{40}$, co wynika przede wszystkim $\mathrm{w}$ powiększającej się odległości między miejscem zamieszkania a nielicznymi, dostępnymi jeszcze, miejscami pracy, które dodatkowo stale migrują w poszukiwaniu taniej siły roboczej.

Podobne związki z masowym ubożeniem ma wymuszana przez międzynarodowe instytucje finansowe polityka cięcia wydatków publicznych, która prowadzi do zwijania się polityki wewnętrznej państw i likwidowania większości programów publicznych. Szczególnie brzemienne w skutki jest wprowadzenie zasady odzyskiwania kosztów w przypadku ochrony zdrowia i edukacji. Nieco subtelniejszym sposobem uszczuplania kompetencji państwa jest $z$ kolei wprowadzenie zasady pomocniczości, którą definiuje się jako przekazywanie suwerennej władzy niższym szczeblom, a zwłaszcza organizacjom pozarządowym. Problem w tym, że są one bezpośrednio powiązane z głównymi międzynarodowymi agencjami pomocy ${ }^{41}$, które realizują zachodni model pomocy przez uzależnienie. Być może dlatego „w Urban Policy and Economic Development: An Agenda for the 199 OS (...) na nowo określono zadania sektora publicznego, które mają polegać na wspieraniu rozwoju rynku" 42 .

Podsumowując, do najbardziej dotkliwych skutków polityki neoliberalnej należą zmiany dokonujące się na rynku pracy, ponieważ wywołują głęboką restrukturyzację społeczną. $\mathrm{W}$ ich rezultacie następuje redukcja i uelastycznienie zatrudnienia. Dominują prace krótkoterminowe, dorywcze, podwykonawcze, wolontariackie i tzw. praca śmieciowa za bardzo niskie stawki i bez zabezpieczeń socjalnych. Niechętnie zatrudniani są nieelastyczni pracownicy ${ }^{43}$. Radykalne odchudzanie państwa powoduje utratę licznych miejsc pracy w sektorze publicznym. Delegowanie pracy w rejony o tańszej sile roboczej dodatkowo zmniejsza zapotrzebowanie na pracowników w centrum i powoduje rozwój niewolniczej pracy na peryferiach. W konsekwencji tego pracujący znaleźli się obecnie $\mathrm{w}$ niewiele lepszej sytuacji aniżeli

\footnotetext{
39 Tamże, s. 234.

40 Tamże, s. 245.

41 Tamże, s. 217.

42 Tamże, s. 229.

${ }^{43}$ R. Sennett, Korozja charakteru. Osobiste konsekwencje pracy w nowym kapitalizmie, przekł. J. Dzierzgowski, Ł. Mikołajewski, Warszawa 2006, s. 125.
} 
bezrobotni. Narastająca niepewność zatrudnienia stwarza zaś nową psychologicznie sytuację na rynku pracy, gdzie wielu walczy o nieliczne miejsca pracy ${ }^{44}$.

Postępujące $\mathrm{w}$ związku z tym rozwarstwienie i ubożenie społeczeństw powoduje wzrost barier $\mathrm{w}$ dostępie do edukacji i udziału $\mathrm{w}$ życiu publicznym. Na skutek wzrostu bezrobocia i migracji ekonomicznej odłączają się deprywowane kulturowo podklasy, skupione w obszarach bez wstępu i bez dróg wyjścia. Ich szanse na inkluzję wraz z kolejnymi falami neoliberalizacji zdają się coraz bardziej przesądzone. Warto w tym miejscu przywołać cytowane przez Jeana Zieglera słowa Jacquesa Rouxa:

wolność jest jedynie pustym słowem, jeśli jedna grupa ludzi może bezkarnie głodzić inną grupę. Równość jest jedynie pustym słowem, jeśli bogacz, korzystając z prawa monopolu, staje się panem życia i śmierci innego człowieka ${ }^{45}$.

Jednakże, polityka neoliberalna „stawia mur epistemologiczny, który blokuje jakąkolwiek uczciwą debatę o codziennej przemocy ekonomicznego wykluczenia" 46 .

Opisane wyżej liberalne i neoliberalne praktyki wykluczenia mają związek z procesami reprodukcji porządku społecznego i jak pisze B. Bernstein noszą wszelkie znamiona procesu pedagogicznego, na który składają się wszystkie jawne i niejawne pedagogie, obecne w sferze prywatnej i publicznej ${ }^{47}$. Dlatego, wywodzę zobowiązanie pedagogów do podejmowania wysiłku ich deszyfrowania.

\section{BIBLIOGRAFIA}

Agacinski S., Polityka ptci, przekł. M. Falski, Wydawnictwo KR, Warszawa 2000.

Arendt H., Kondycja ludzka, przekł. A. Łagodzka, ALETHEIA, Warszawa 2000.

Bauman Z., Praca, konsumpcjonizm i nowi ubodzy, przekł. S. Obirek, Wydawnictwo WAM, Kraków 2006.

Beauvoir S. de, Druga płeć, Wydawnictwo Literackie, Kraków 1972.

Benhabib S., Trzy modele przestrzeni publicznej, przekł. A. Ostolski, „Krytyka Polityczna” z 2003, 3 .

Bensaid D., Wywtaszczeni. Marks, własność i komunizm, przekł. Z.M. Kowalewski, Instytut Wydawniczy Książka i Prasa, Warszawa 2010.

44 Z. Bauman, Praca, konsumpcjonizm i nowi ubodzy, przekł. S. Obirek, Kraków 2006.

45 J. Roux, Manifeste des Engrales, przedstawiona Konwentowi 25 czerwca 1793 roku, cyt. za: J. Ziegler, Imperium hańby, przekł. E. Cylwik, Warszawa 2011, s. 36.

46 Tamże, s. 280.

47 B. Bernstein, Odtwarzanie kultury, przekł. Z. Bokszański, A. Piotrowski, Warszawa 1990, s. 72 . 
Bernstein B., Odtwarzanie kultury, przekł. Z. Bokszański, A. Piotrowski, PIW, Warszawa 1990.

Davis M., Planeta slumsów, przekł. K. Bielińska, Instytut Wydawniczy Książka i Wiedza, Warszawa 2009.

Engels F., Pochodzenie rodziny, własności prywatnej i państwa, [w:] K. Marks, F. Engels, Dzieła, t. 21, Wydawnictwo Książka i Wiedza, Warszawa 1969.

Friedman M., (przy współpracy R. Friedman), Kapitalizm i wolność, przekł. M. Lasota, A. Kondratowicz, Wydawnictwo Centrum im. Adama Smitha i "Rzeczpospolita”, Warszawa 1993.

Friedman M. i R., Wolny wybór, przekł. J. Kwaśniewski, Wydawnictwo Aspekt, Sosnowiec 2006.

Gordon Th., Wychowanie bez porażek, przekł. D. Szafrańska-Poniewierska, IW PAX, Warszawa 2004.

Harvey D., Neoliberalizm. Historia katastrofy, przekł. J.P. Listwan, Instytut Wydawniczy Książka i Prasa, Warszawa 2008.

Hayek F.A. von, Droga do zniewolenia, przekł. K. Gurba, L. Klyszcz, J. Margański, D. Rodziewicz, Wydawnictwo ARCANA, Kraków 2003.

Hessen S., Pisma pomniejsze, [w:] Dzieła wybrane, wybór i oprac. W. Okoń, t. V, Wydawnictwo Akademickie Żak, Warszawa 1997.

Heywood A., Ideologie polityczne. Wprowadzenie, przekł. M. Habura, N. Orłowska, D. Stasiak, Wydawnictwo Naukowe PWN, Warszawa 2007.

Lewartowska-Zychowicz M., Homo liberalis jako projekt edukacyjny. Od emancypacji do funkcjonalności, Oficyna Wydawnicza Impuls, Kraków 2010.

Locke J., Dwa traktaty o rządzie, przekł. Z. Rau, Wydawnictwo Naukowe PWN, Warszawa 1992.

Manent P., Intelektualna historia liberalizmu, przekł. M. Miszalski, Wydawnictwo ARCANA, Kraków 1994.

Mill J. S., Poddaństwo kobiet, [w:] O rządzie reprezentatywnym, przekł. J. Hołówka, Społeczne Wydawnictwo Znak, Kraków 1995.

Mises L. von, Liberalizm w tradycji klasycznej, przekł. S. Czarnik, Wydawnictwo ARCANA, Kraków 2001.

Mises L. von, Mentalność antykapitalistyczna, przekł. J.M. Małek, Wydawnictwo ARCANA, Kraków 1999.

Piński A., Polska biedna na zawsze, „Wprost” z 10 grudnia 2012.

Putnam Tong R., Myśl feministyczna. Wprowadzenie, przekł. J. Mikos, B. Umińska, Wydawnictwo Naukowe PWN, Warszawa 2002.

Rand A., Rasizm, [w:] Powrót człowieka pierwotnego. Rewolucja antyprzemystowa, przekł. Z.M. Czarnecki, Wydawnictwo Zysk i S-ka, Poznań 2003.

Roux J., Manifeste des Engrales, przedstawiona Konwentowi 25 czerwca 1793 roku, cyt. za Jean Ziegler, Imperium hańby, przekł. E. Cylwik, Instytut Wydawniczy Książka i Prasa, Warszawa 2011.

Sennett R., Korozja charakteru, Osobiste konsekwencje pracy w nowym kapitalizmie, przekł. J. Dzierzgowski, Ł. Mikołajewski, Wydawnictwo Literackie MUZA, Warszawa 2006.

Stodolak S., Absurd patentowany, "Wprost” z 11 września 2011.

Wróbel S., Nawrocki R., Szkota jako fikcja i inne szkice z filozofii edukacji, Wydawnictwo Naukowe UAM, Kalisz-Poznań 2010.

Young I., Beyond the unhappy marriage: a critique of the dual systems theory, [w:] Women and revolution: a discussion of the unhappy marriage of marxism and feminism, red. L. Sargent, South End Press, Boston 1981. 